\title{
Correlation Between Thinking Styles and Teaching Styles of Prospective Mathematics Teachers
}

\author{
Beyza Balamir Apaydin ${ }^{1} \&$ Selin (Inag) Cenberci ${ }^{2, *}$ \\ ${ }^{1}$ Institute of Educational Sciences, Necmettin Erbakan University, Turkey \\ ${ }^{2}$ Department of Mathematics Education, Ahmet Kelesoglu Education Faculty, Necmettin Erbakan University, \\ Turkey \\ *Correspondence: Necmettin Erbakan University, Turkey. E-mail: scenberci@konya.edu.tr
}

Received: June 26, $2018 \quad$ Accepted: July 11, $2018 \quad$ Online Published: July 23, 2018

doi:10.5430/wje.v8n4p36 URL: https://doi.org/10.5430/wje.v8n4p36

\begin{abstract}
Increasing the quality of education is based on changes thinking and teaching styles. Considering variance of thinking styles and teaching styles person to person, identifying thinking styles and teaching styles of prospective mathematics teachers is very important. So, the aim of this study is to determine the correlation between thinking and teaching styles of prospective mathematics teachers and to examine thinking styles and teaching styles of the prospective mathematics teachers by considering some demographic characteristics. The sample of the research consisted of 80 prospective mathematics teachers who studied at the Mathematics Education Department of Ahmet Keleşoğlu Education Faculty at Necmettin Erbakan University. Relational screening model was used in analysis of the data. "Thinking Styles Scale" which was developed by Sternberg and Wagner (1992) and adapted to Turkish by Buluş (2006) and "Teaching Style Inventory" developed by Grasha (1994) and adapted to Turkish by Uredi (2006) were used as data collection tool in the research. According to the conclusion of the research, a positive moderate correlation was found between thinking styles and teaching styles of prospective mathematics teachers.
\end{abstract}

Keywords: prospective mathematics teacher, thinking styles, teaching styles

\section{Introduction}

\subsection{Introduce the Problem}

Thinking is the basic characteristic of individuals separating them from other beings and it is a process aiming individual to reach to the most accurate result. While eating, reading, studying, dreaming or in all other activities individuals need to think. According to Ozden (2005) thinking is that the way to discipline analysis and evaluation of the information obtained from observation, experience and reasoning.

Thinking is decribed as the situation that individuals are in active, goal-oriented, organized mental process (Canbolat, 2011). Nickerson (1988) suggests that thinking is a process that contains problem solving, deciding, critical thinking and locigal reasoning. Developed societies, consist of individuals who use these steps of thinking process in every field. This process varies from person to person. This, reveals the concept of thinking styles emerges. Thinking styles are not abilities but preferences to perform abilities. In addition to the thinking styles interact with socialization processes changing according to task, situation and most importantly individual differences and vary through the life.

Sternberg ve Zhang (2005) described thinking styles as the think done when using ability or a way of preference of thinking.

Individuals use different styles in their daily routines. While choosing the styles they decide the most suitable one for them. Styles can not be described as good or bad. The most comprehensive study related to thinking styles is "Mental Self Government Theory" of Sternberg (1997). Sternberg in his theory argues that people need to govern themselves and organize their daily activites. In the theory, it is stated that thinking styles are not abilities but preferences in using abilities. From the harmony of style emerges a synergy and abilities. People do not have a style but have a style profile and these styles differ according to the situations. In addition, it is emphasized that styles can be teached, measured, varied through the life, changed and they are not good or bad (Dincer, 2009). 
Also, in his theory Sternberg appeared thirteen thinking styles under five basic dimensions as functions (legislative, executive, judmental), forms (hierarchical, monarchic, oligarchic, anarchic), levels (global, local), fields (intrinsic, extrinsic), tendencies (liberal, conservative).

1. Functions: Individuals who are focused on creativity and planning in a legislative thinking style want to be in situation where they can express their ideas. The individual with executive thinking style is more concerned with having a set of regular, guiding principles and taking part in the work in which the instructions are stated. They enjoy working in a planned way. Individuals with a judmental-thinking style are focused on evaluation and comparison.

2. Forms: The individual who exhibits a perfectionist attitude in the style of monarchic thinking enjoys participating in the fully focused work. In a hierarchical thinking style, an individual deal with many tasks, but works by determining priority sequences. An individual with an oligarchic thinking style strives for many objectives at the same time, but does not like to determine the priorities. Individuals in the style of anarchic thinking concentrate on works that are not dependent on anything and do not cause anxiety.

3. Levels: An individual who thinks in local (local) thinking style, enjoy dealing with works by paying attention to details, and contrary to this, an individual with a global thinking style tries to pay attention to an entire idea.

4. Fields: An individual with an intrinsic thinking style prefers to work in jobs that can work freely without depended on someone. In the style of extrinsic thinking, the individual enjoys of intra-group co-operation.

5. Tendencies: A person in the conservative thinking style wants to conduct the work by following the rules. An individual with liberal thinking style is open to innovations, does not avoid the uncertainty and unknown works.

Researches reveal that the thinking style is a property that affects and alters the individual when he or she realise the things (Bulus, 2005). Therefore, creating a sufficient and strong awareness of the concept of thinking style is an educational need. Because a teacher who thinks in the educational process can raise students who are creative, problem-solving and can think critically and comment. Zhang (2003) defines the thinking style as a method that determines how an individual learns information and how to use the information, so it is important for both teachers and students to know what kind of thinking style they have. Considering that an individual use these thinking styles in every aspect of the life, it is not possible to disregard a teacher's use of thinking style teaching in the educational system as well.

Some teachers choose a teaching style that is suitable to their personality, teaching psychology, their thinking styles and they think it is the best. But not for themselves, teachers should also use teaching styles that appeal to students' different personalities, needs and teaching styles that arise from these differences. Because teaching styles are the leading factors that shape the teaching-learning process and have the most important part in achieving students' success. It is very important for teachers to use different teaching styles, taking into consideration the individual differences of students to provide high quality education.

In the learning-teaching process of teachers, the style of presenting information, the ability to communicate with students, the behaviour of the students to socialise, is a reflection of the style of teaching they possess. According to Dunn \& Dunn (1979), the teaching style is the attitude and behaviour of teachers' about to the teaching programs, methods, teaching environments and the tools which they use. According to Cooper (1999), the teaching style covers the behaviors that teachers show for managing the classroom. The teaching style is defined as the complementing behavior that the teacher uses to achieve the target behaviour and to achieve successful results (Fischer \& Fischer, 1979).

The teaching style by Heimlich \& Norland (2002), is defined effort to combine with their behaviour in the learning-teaching process the teachers' beliefs and values. According to Conti (1985), the teaching style is a typical teaching that a teacher consistently uses. Maden (2012), states that teaching styles are associated with topics such as sharing information in a classroom environment, interact with students. According to Grasha (2002), the systematic sense of style is what a teacher does or what does not do. Namely, we can express that the teacher is in the form of behaviors that are consistent with the interactions in the teaching process. Teachers can use different styles of teaching according to their situation. So a teacher may not have only one teaching style. According to Grasha, teaching style models are as follows:

1) Expert teaching style: Teachers who provide detailed information and have the knowledge and experience students' need, develop their knowledge and prepare them well. However, it may not be sufficient to show the target behaviour expected from the student only by transmitting information.

2) Formal authority teaching style: The aim of the teacher in this style is to give students feedback, to determine the 
purpose and rules. It deals with correct, accepted and standard ways to do something. The expectations at the point of doing things with acceptable methods are clear. In this approach, teachers do not change and they manage students in strict, standard ways and this style ignores their interests.

3) Personal teaching style: This style of teaching is specific to the person who is concerned about how to think and how to behave. Teachers with this style encourage students to observe and practice the approach of the teacher by showing how things are done. The teacher checks them, shows the path, and directs them. Observe and follow a model is important. Some teachers may consider their approach to be the best and the only one, or they agree the idea that students will be inadequate if this approach is not applied.

4) Facilitator teaching style: The biggest aim for teachers in this style is to be able to treat students independently and develop awareness of responsibility. The teacher guides them by asking questions, examining students' ideas. He or she is a guider for students. When teachers are viewing and implementing different teaching approaches according to their students', this style is time-consuming and when it is not applied positively, the desired result may not be obtained.

5) Delegator teaching style: The teacher who answers the questions and regularly controls the tasks given to the students, by providing students to manage their own capacity by taking care of the development of them individualy or as a group prepare suitable environments in which they can work independently in their projects. But students may be concerned if they are not ready to work independently.

Grasha has identified 10 teaching roles, taking into consideration the interaction of teachers and students. Also teaching styles have been created by taking into consideration these roles. That's why we prefer Grasha's teaching styles. In addition, Grasha emphasizes that each of these teaching styles is not superior to the others (Grasha, 1994; Grasha, 1996; Grasha, 2002).

\subsection{Literature Review}

When the literature was examined, there was not any study of the two subjects together examine. However, these two subjects were examined separately depending on different variables. In the study of the teachers' features and thinking styles Zhang and Sternberg (2002), it was determined that the thinking styles of the teachers vary according to their characters and the ideology of the schools where they work. As a result of his work to determine the thinking styles of the teacher candidates Cubukcu (2004), reveals that a high proportion of the students prefer rules and hierarchical thinking styles, while conservative and local thinking styles are preferred at a low rate. Also in terms of gender, thinking styles no significant difference was found. In another study of Cubukcu (2004a), whether the thinking styles are influenced in determining the learning patterns or not were investigated. As a result of the research, it was determined that the teacher candidates have a high proportion of the rules and hierarchical thinking styles. According to some thinking styles, the branch and gender are determined to be effective. It was also determined that thinking styles are effective in determining learning patterns.

In some studies, thinking styles were examined in terms of various variables. For example, in the study conducted on classroom teachers, some variables such as age, gender, educational background and a significant relation between them were examined, but no significant relation was found (Tuzer, 2016). Celik (2016), in his work compared $11^{\text {th }}$ grade students's thinking styles and learning strategies. As a result of the study, according to all types of schools, there were a negative relation between the thinking styles and learning strategies that the student used and when the school types were examined seperately it was determined that there was a positive relation between judicial thinking style and repetition and organization strategy and between the global thinking style and the understanding of monitoring comprehension strategies. Apart from these, the thinking styles in the literature; there are studies examining according to variables such as literacy self-sufficiency, reflective thinking, and thinking needs. Among these in the study conducted by Cinar in 2016 the relationship between thinking styles and reflective thinking trends were examined and in the result of the study it was found that the highest relation was between the judicial thinking and investigative reflective style, between hierarchical thinking and investigative reflective thinking styles and between hierarchical thinking and intrinsic reflective thinking styles.

In the research of Yildirim (2016), the relationship between thinking styles and mathematics literacy self sufficiency was examined. According to the outcome of the study, the scores of thinking styles of classroom and mathematics teachers mathematics literacy self-competences', legislative, executive, judicial, hierarchical and liberal in general are "high", while global, oligarchic and conservative thinking styles were found to be lower. In the study of Uyanik (2017), the relationship between thinking needs and thinking styles was examined and concluded that there is a significant difference between them. In addition to this, the most preferred thinking styles of mathematics teacher candidates were respectively legislative, executive and the conservative thinking styles. In general, there are 
significant differences between the thinking styles of teacher candidates and gender, class and section variables. Although there were significant differences between the reflective thinking trends and gender and section variables, there was no significant difference between the class variables. Ince, Cenberci \& Yavuz (2018), wanted to determine relationship between the attitudes of mathematics teacher candidates towards scientific research and their thinking style. And they found no significant relationship between the thinking styles of the teacher candidates and their attitudes towards scientific research.

The studies on teaching styles are generally based on determining the teaching styles of teacher candidates according to their branches. Artvinli (2010), determined the teaching styles of the geography teachers in his study, and as a result, it was determined that teacher use memorisation-based and teacher-centered passive teaching styles.

Maden (2012), in his study for determining the teaching styles of Turkish lesson teachers revealed that Turkish lesson teachers highly have personal and facilitator teaching styles and low proportion of expert teaching style. In his study examining perceptions of prospective music teachers about teaching styles in 2016, Ahmethan found a significant relationship between prospective teachers' teaching styles and practice school counselors' teaching styles. Unal with the work in 2017 aimed to determine the teaching styles of teachers and prospective teachers and it was found that teachers have expert, formal authorty teaching styles while the prospective teachers have facilitator model teaching style. In the study of Beyhan (2018), investigated the perception of teaching styles of prospective music teachers in the practice school and in the result of study it was found the most preferred styles were expert, demonstrator and the number of the students only changed the perception of the practice teachers in delegator teaching style. Zhang (2005), discussed the teaching styles of teachers in terms of the approaches of the student from USA and Hong Kong and researched which teaching styles students mostly preferred and found that the students mostly preferred specific teaching styles instead of traditional thinking styles.

\subsection{Explore Importance of the Problem}

Today, mathematics is still one of the most feared lessons and the success is lower than the other lessons. The success of mathematics depends on a number of variables, such as the way the teacher teachs it and behaviors in the class. Since the first way to increase success depends on teachers' behaviour in the class and so the examination of the way of teaching is a very important issue in this study. Also considering that teaching styles are influenced by many variables, it is aimed to investigate whether the thinking styles are effective when determining the teaching styles of prospective mathematics teachers. Results from this study are very important in terms of strengthening the validity and reliability of the studies available in the literature and filling the gap in the relevant field. It has not been found such a study in the literature. Therefore, it is thought that this work will be a precursor to subsequent studies.

\subsection{Research Questions}

This study aims to investigate whether there is a relationship between thinking styles and teaching styles by determining thinking styles and teaching styles of the prospective mathematics teachers and to examine effect of the demographic characteristics such as gender and graduated high school. In this context, the question "is there a correlation between the thinking styles and the teaching styles of the prospective mathematics teachers?" was determined the problem phrase and with this aim the following sub-problems were researched.

1. What are the thinking styles of prospective mathematics teachers?

2. Do the demographic characteristics of prospective mathematics teachers have effect on thinking styles?

3. What are the teaching styles of prospective mathematics teachers?

4. Is there any effect on the teaching styles of the demographic characteristics of the prospective mathematics teachers?

5. Is there a significant relationship between the teaching styles and thinking styles of prospective mathematics teachers?

\section{Method}

In this study, prospective mathematics teachers' teaching styles and thinking styles are tried to be determined. In the research, since the situation is tried to be determined as it has been, it is a descriptive research, general screening model was used. Screening model is defined a study of the research activities in which the participants' talents or opinions about a situation are determined (Buyukozturk et al., 2017). It should also be noted that prospective mathematics teachers' teaching styles and thinking styles are examined about the demographic characteristics. By this way, this study is a relational research model. 


\subsection{Universe and Sample}

Universe of study consist of 80 prospective mathematics teachers in Mathematics Education Department at Necmettin Erbakan University.

\subsection{Data Collection Tool}

The "Teachers Teaching Styles Inventor" developed by Grasha (1994) and adapted to Turkish by Üredi (2006) and "Thinking Styles Scale" developed by Sternberg and Wagner (1992) adapted to Turkish by Buluş (2006) was used as a data collection tools. Teachers Teaching Styles Scale is a likert type measure consisting of five factors 40 questions, namely "Expert teaching style", "Formal Authority teaching style", " Personal teaching style", "Facilitator teaching style" and "Delegator teaching style". Each style is calculated with 8 articles in the inventory to determine teaching styles. Following the applied scale, the data are analyzed using the rating scales and there are five options on the scale. For the four intervals in the quinary scale $(5-1=4)$ interval coefficient is $(4 / 5) 0,80$. (Definitely do not agree $1-1.79$, do not agree 1.80- 2.59, neutral 2.60-3.39, I agree 3.40-4.19 and completely agree 4.20-5). The thinking style scale is a likert type scale consisting of 65 questions with 13 factors. Five questions are asked for each style to determine the style of thinking. Following the applied scale, there are 7 options on the scale. For the 6 intervals in the septette scale (7-1=6) interval coefficients are (6/7) 0.85. (HUD: Not applicable, ÇUD: Not Very Applicable, BU: Fairly Good, CU: Very Applicable, TU: Completely Applicable).

\subsection{Analysis of Data}

Data analysis were done on a computer and SPSS 22 computer package program. The arithmetic average and standard deviation values of teaching styles and thinking style scores were determined to the prospective mathematics teachers who are studying in Mathematics Education Department. In addition, a correlation coefficient was calculated to see there a significant relationship between thinking styles and teaching styles of the prospective mathematics teachers.

\section{Findings}

\subsection{First Sub-Problem}

The first sub-problem sentence of the study is "What are the styles of thinking of prospective mathematics teachers?" In order to answer this sub-problem, the descriptive statistical data are examined and Table 1 gives the arithmetic mean and standard deviation values of the thinking styles of the prospective mathematics teachers.

Table 1. Descriptive Statistical Data of Prospective Mathematics Teachers Own Thinking Styles

\begin{tabular}{llcr}
\hline Thinking Styles & $\boldsymbol{N}$ & $\overline{\boldsymbol{X}}$ & \multicolumn{1}{c}{$\boldsymbol{S S}$} \\
\hline Legislative & 80 & 5,6775 &, 91375 \\
Executive & 80 & 5,3425 & 1,11931 \\
Judmental & 80 & 5,1950 & 1,13894 \\
Monarchic & 80 & 4,7325 & 1,17093 \\
Hierarchical & 80 & 5,2475 & 1,06604 \\
Oligarchic & 80 & 4,3675 & 1,22276 \\
Anarchic & 80 & 4,7375 & 1,17467 \\
Global & 80 & 4,3750 & 1,36331 \\
Local & 80 & 4,5275 & 1,27815 \\
İntrinsic & 80 & 4,8475 & 1,26980 \\
Extrinsic & 80 & 4,7200 & 1,14896 \\
Open minded (Liberal) & 80 & 5,3000 & 1,18086 \\
Conservative & 80 & 3,6600 & 1,52495 \\
\hline
\end{tabular}

When Table 1 is examined, it is seen that the most preferred thinking styles of the prospective mathematics teacshers are respectively creativity and planning oriented "legislative" thinking, guidance oriented "executive" thinking, "open minded" style of thinking and by determining the precedence study oriented "hierarchic" thinking style. The least preferred way of thinking is the "conservative" way of thinking.

According to the findings in Table 1, we can say that the prospective mathematics teachers are open to innovations and developments and they tend to exploring, in addition to these they want to be outside of the traditional education concept. 


\subsection{Second Sub-Problem}

The second sub-problem sentence of the study is "Do the demographic characteristics of the prospective mathematics teachers have an effect on the thinking styles?" In order to answer this sub-problem, descriptive statistics were examined and since according to Kolmogorov-Smirnov normality test results points have normal distribution, independent groups t-test was applied to determine whether there was a significant difference between gender and graduation school variables and prospective mathematics teachers' thinking styles. The data are given in Table 2 and Table 3, respectively.

Table 2. Statistical Data on Gender and Thinking Styles of Prospective Mathematics Teachers

\begin{tabular}{llrlrl}
\hline Thinking Styles & Gender & $\boldsymbol{N}$ & $\overline{\boldsymbol{X}}$ & $\boldsymbol{S S}$ & $\boldsymbol{p}$ \\
\hline Legislative & Female & 55 & 5,6109 &, 91280 &, 337 \\
& Male & 25 & 5,8240 &, 91710 &, 340 \\
Executive & Female & 55 & 5,2618 & 1,14496 &, 342 \\
& Male & 25 & 5,5200 & 1,06145 &, 330 \\
Judmental & Female & 55 & 5,1018 & 1,16484 &, 281 \\
& Male & 25 & 5,4000 & 1,07393 &, 268 \\
Monarchic & Female & 55 & 4,7055 & 1,18750 &, 761 \\
& Male & 25 & 4,7920 & 1,15539 &, 760 \\
Hierarchical & Female & 55 & 5,1782 & 1,07129 &, 392 \\
Oligarchic & Male & 25 & 5,4000 & 1,05987 &, 392 \\
& Female & 55 & 4,2509 & 1,23181 &, 208 \\
Anarchic & Male & 25 & 4,6240 & 1,18648 &, 204 \\
& Female & 55 & 4,5309 & 1,16569 &, 019 \\
Global & Male & 25 & 5,1920 & 1,08240 &, 017 \\
& Female & 55 & 4,3018 & 1,36673 &, 480 \\
Local & Male & 25 & 4,5360 & 1,36957 &, 482 \\
& Female & 55 & 4,3964 & 1,25048 &, 175 \\
Intrinsic & Male & 25 & 4,8160 & 1,31646 &, 186 \\
& Female & 55 & 4,7564 & 1,31751 &, 344 \\
Extrinsic & Male & 25 & 5,0480 & 1,15799 &, 322 \\
\multirow{2}{*}{ Open Minded } & Female & 55 & 4,4400 & 1,07248 &, 001 \\
(Liberal) & Male & 25 & 5,3360 & 1,08738 &, 001 \\
& Female & 55 & 5,1055 & 1,21707 &, 028 \\
Conservative & & 25 & 5,7280 &, 98975 &, 019 \\
Thinking Styles & Male & 55 & 3,5564 & 1,53753 &, 371 \\
& Female & 25 & 3,8880 & 1,50231 &, 368 \\
\hline & Male & 55 & 4,7074 &, 64813 &, 027 \\
& Memale & 25 & 5,0849 &, 78958 &, 043 \\
\hline & & & &
\end{tabular}

According to the findings obtained from the independent group $t$ test on the scores of the prospective mathematics teachers according to the gender variable of the thinking style scale, it was obtained that "anarchic" thinking style, "extrinsic" thinking style and "open minded" thinking styles and "Thinking Styles of prospective mathematics teachers generally" were significantly different according to gender $(\mathrm{p}<0.05)$.

As seen in Table 2, it is concluded that male prospective mathematics teachers have a higher average score than female prospective mathematics teachers in sub-factors of thinking styles "open minded", "anarchic", "extrinsic" and "Thinking Styles of prospective mathematics teachers generally". 
Table 3. Statistical Data on Graduated High School and Thinking Styles of Prospective Mathematics Teachers

\begin{tabular}{lllrrr}
\hline Thinking Styles & Graduated High Schools & $\boldsymbol{N}$ & $\overline{\boldsymbol{X}}$ & \multicolumn{1}{c}{$\boldsymbol{S . S}$} & $\boldsymbol{p}$. \\
\hline Legislative & Other & 38 & 5,6842 &, 99472 &, 951 \\
& Anatolian High School & 42 & 5,6714 &, 84602 &, 951 \\
Executive & Other & 38 & 5,2316 & 1,24382 &, 403 \\
& Anatolian High School & 42 & 5,4429 &, 99808 &, 408 \\
Judmental & Other & 38 & 5,3632 &, 99497 &, 211 \\
& Anatolian High School & 42 & 5,0429 & 1,24746 &, 206 \\
Monarchic & Other & 38 & 4,6895 & 1,27826 &, 757 \\
& Anatolian High School & 42 & 4,7714 & 1,07891 &, 759 \\
Hierarchical & Other & 38 & 5,2947 & 1,22031 &, 709 \\
& Anatolian High School & 42 & 5,2048 &, 91757 &, 713 \\
Oligarchic & Other & 38 & 4,3526 & 1,25413 &, 918 \\
& Anatolian High School & 42 & 4,3810 & 1,20876 &, 919 \\
Anarchic & Other & 38 & 4,7632 & 1,23276 &, 854 \\
& Anatolian High School & 42 & 4,7143 & 1,13408 &, 855 \\
Global & Other & 38 & 4,1000 & 1,44053 &, 086 \\
& Anatolian High School & 42 & 4,6238 & 1,25500 &, 089 \\
Local & Other & 38 & 4,7053 & 1,26895 &, 239 \\
& Anatolian High School & 42 & 4,3667 & 1,28018 &, 239 \\
Intrinsic & Other & 38 & 4,6684 & 1,29971 &, 233 \\
& Anatolian High School & 42 & 5,0095 & 1,23522 &, 234 \\
Extrinsic & Other & 38 & 4,8368 & 1,11681 &, 390 \\
& Anatolian High School & 42 & 4,6143 & 1,18065 &, 389 \\
Open Minded & Other & 38 & 5,3789 & 1,16414 &, 573 \\
& Anatolian High School & 42 & 5,2286 & 1,20533 &, 572 \\
Conservative & Other & 38 & 3,6526 & 1,57801 &, 968 \\
& Anatolian High School & 42 & 3,6667 & 1,49449 &, 968 \\
Thinking Styles & Other & 38 & 4,8247 &, 75894 &, 994 \\
& Anatolian High School & 42 & 4,8260 &, 67688 &, 994 \\
\hline \multirow{2}{*}{ S } & & & &
\end{tabular}

When Table 3 was examined, it was seen that there was no significant difference when examining prospective mathematics teachers' thinking style scores according to graduated high school ( $\mathrm{p}>0.05)$.

\subsection{Third Sub-Problem}

The third sub-problem sentence of the study is "What are the teaching styles of prospective mathematics teachers?" In order to answer this sub-problem, descriptive statistical data was examined and in Table 4 the arithmetic mean and standard deviation values of teaching styles of prospective mathematics teachers are given.

Table 4. Descriptive Statistical Data of Prospective Mathematics Teachers' Own Teaching Styles

\begin{tabular}{lccc}
\hline Teaching Styles & $\boldsymbol{N}$ & $\overline{\boldsymbol{X}}$ & $\boldsymbol{S . S}$ \\
\hline Expert & 80 & 4,0422 &, 56568 \\
Formal Authority & 80 & 3,8188 &, 58728 \\
Personal & 80 & 4,0500 &, 59984 \\
Delegator & 80 & 3,9016 &, 60806 \\
Facilitator & 80 & 4,2172 &, 63668 \\
\hline
\end{tabular}

When Table 4 was examined, it was seen that the most preferred teaching styles were "facilitator", "expert", "personal" and "delegator" teaching styles and least preferred teaching styles is "formal authority" teaching style.

\subsection{Fourth Sub-Problem}

The fourth sub-problem sentence of the study is "Do the demographic characteristics of the prospective mathematics teachers have an effect on teaching styles?" In order to answer this sub-problem, descriptive statistical data were examined and since the teaching styles of the prospective mathematics teachers with normal distribution according to 
Kolmogorov-Smirnov normality test results, independent groups t-test was applied to determine whether there was a significant difference between the gender and graduated school of the prospective mathematics teachers. The data are given in Table 5 and Table 6, respectively.

Table 5. Statistical Data on Gender and Teaching Styles of Prospective Mathematics Teachers

\begin{tabular}{llcccc}
\hline Teaching Styles & Gender & $\boldsymbol{N}$ & $\overline{\boldsymbol{X}}$ & $\boldsymbol{S S}$ & $\boldsymbol{p}$ \\
\hline Expert & Female & 55 & 4,0386 &, 51923 &, 934 \\
& Male & 25 & 4,0500 &, 66829 &, 940 \\
Formal Authority & Female & 55 & 3,8341 &, 55593 &, 731 \\
& Male & 25 & 3,7850 &, 66195 &, 749 \\
Personal & Female & 55 & 4,0659 &, 57022 &, 727 \\
& Male & 25 & 4,0150 &, 67152 &, 744 \\
Facilitator & Female & 55 & 4,2477 &, 49622 &, 528 \\
& Male & 25 & 4,1500 &, 87945 &, 211 \\
Delegator & Female & 55 & 3,9591 &, 51598 &, 284 \\
& Male & 25 & 3,7750 &, 77055 & $\mathbf{, 5 5 2}$ \\
Teaching Styles & Female & $\mathbf{5 5}$ & $\mathbf{4 , 0 2 9 1}$ & $\mathbf{4 4 0 5 1}$ & $\mathbf{6 0 8}$ \\
\hline
\end{tabular}

When Table 5 was examined, no significant difference was found between gender and teaching styles of prospective mathematics teachers $(\mathrm{p}>0.05)$.

Table 6. Statistical Data on Teaching Styles and the Prospective Mathematics Teachers Graduated School

\begin{tabular}{|c|c|c|c|c|c|}
\hline Teaching Styles & Graduated High School & $N$ & $\overline{\bar{X}}$ & SS & $p$ \\
\hline \multirow[t]{2}{*}{ Expert } & Other & 38 & 4,0033 & 54640 & 562 \\
\hline & Anatolian High School & 42 & 4,0774 & ,58692 & ,560 \\
\hline \multirow[t]{2}{*}{ Formal Authority } & Other & 38 & 3,7763 & 63416 & 542 \\
\hline & Anatolian High School & 42 & 3,8571 & 54631 & ,545 \\
\hline \multirow[t]{2}{*}{ Personal } & Other & 38 & 3,9737 & 62477 & 282 \\
\hline & Anatolian High School & 42 & 4,1190 & ,57511 & 284 \\
\hline \multirow[t]{2}{*}{ Facilitator } & Other & 38 & 4,2566 & 58842 & 602 \\
\hline & Anatolian High School & 42 & 4,1815 & 68254 & ,599 \\
\hline \multirow[t]{2}{*}{ Delegator } & Other & 38 & 3,8750 & 57319 & ,713 \\
\hline & Anatolian High School & 42 & 3,9256 & 64396 & ,711 \\
\hline \multirow[t]{2}{*}{ Teaching Styles } & Other & 38 & 3,9770 & ,50321 & 634 \\
\hline & Anatolian High School & 42 & 4,0321 & ,52552 & 633 \\
\hline
\end{tabular}

When Table 6 was examined no significant difference was found between graduated high school and teaching styles of prospective mathematics teachers ( $\mathrm{p}>0.05)$.

\subsection{Fifth Sub-Problem}

The fifth sub-problem sentence of the study is "Is there a significant relationship between the prospective mathematics teachers' teaching styles and thinking styles?" In order to answer this sub-problem, descriptive statistical data was examined and in Table 7, correlation calculations were performed to determine whether the prospective mathematics teachers had a significant relationship between the thinking styles and the teaching styles.

Table 7. The Correlation Matrix Belonging to the Prospective Mathematics Teachers' Thinking Styles and Teaching Styles

\begin{tabular}{lcc}
\hline & Thinking Styles & Teaching Styles \\
\hline Thinking Styles & 1 & \\
& 80 & 1 \\
Teaching Styles &, $374^{* *}$ & 80 \\
&, 001 & 80 \\
\hline
\end{tabular}


As shown in Table 7, a positive moderate relationship was found between thinking styles and teaching styles $(\mathrm{p}<0.05)$.

\section{Conclusion and Discussion}

According to research results in respect to their perception of students thinking styles taken under of 13 class as "legislative", "executive", "judgmental", "monarchic", "hierarchical", "oligarchic", "anarchic", "global", "local", "intrinsic", "extrinsic", "open minded" and "conservative" were collected. However, there are five other teaching styles as "expert", "formal authority", "personal", "facilitator" and "delegator".

According to the results obtained from the prospective mathematics teachers' preferred thinking styles respectively "legislative", "executive", "open minded", "hierarchical", "judgmental", "intrinsic", "anarchic", "monarchic", "extrinsic", "local", "global", "oligarchic" and finally the least preferred is "conservative". "legislative", "executive", and "open-minded" thinking styles are the most used styles and therefore it shows prospective mathematics teachers are open to innovation and development, they are prone to research, while the "conservative" style of thinking used at least among the prospective mathematics teachers and this shows prospective mathematics teachers are outside the traditional approach to education. Cubukcu (2004) and Yildirim's (2016) works are similar with our studies results in terms of thinking style used at least preferred.

When the effect of thinking styles was considered separately it was seen that gender has an effect on "anarchic", "extrinsic" and "open minded" sub-dimensions and "thinking styles of prospective mathematics teachers generally". This study matches up with the results of Uyanik (2017) and the results of Cubukcu's (2004a), study on determining learning styles with thinking styles not as separately but in terms of effect of gender on thinking styles generally. Then it can be said that thinking styles can change depending on gender. But there was not found any effect of graduated high school on thinking styles.

When the teaching styles of prospective mathematics teachers was examined, the most preferred to least preferred teaching styles were as "facilitator", "expert", "personal", "delegator" and "formal authority". It is an important point that prospective mathematics teachers preferred at least "formal authority" teaching style and this can show prospective mathematics teachers do not strict to the rules and standards, and they are teachers who care about students' interest and attention. This is similar to the results of Maden's study on determining teaching methods in 2012. As a result of both studies "facilitator" and "personal" teaching style was highly preferred in teaching styles.

The fourth sub-problem of the study "Do the demographic characteristics of the prospective mathematics teachers have an effect on teaching styles?" question was examined and in the conclusion it was determined that gender and graduated school does not have an impact on the type of teaching styles was reached.

Last it was found a positive moderate degree of significant relationship between thinking styles and teaching styles of prospective mathematics teachers. Since the attitude of individuals in every case, reaction, and communication with people or against them will be affected by individuals' thinking styles and also this will affect the teaching style as well. Environments where the prospective mathematics teachers use thinking and teaching styles should be created.

\section{Recommendations}

- Prospective mathematics teacher' thinking styles and teaching styles must be raise their awareness. If necessary, by giving relavant courses about this matter awareness should be increased.

- Similar research can be done on different samples.

- The effect of mathematics teachers' teaching styles on the success of the students in mathematics can be studied.

\section{References}

Ahmethan, B. N. (2016). Correlation between teaching styles of condidate music teachers and mentor music teachers. Educational Research and Reviews, 11(13), 1228-1235. https://doi.org/10.5897/ERR2016.2795

Artvinli, E. (2010). Teaching styles of geography teachers. Electronic Journal of Social Sciences, 9(33), 387-408.

Beyhan, O. (2018). Students perceptions on the Teaching Styles of Their Teachers, Hacettepe Üniversitesi Eğitim Fakültesi Dergisi, 1-11. https://doi.org/ 10.16986/HUJE.2018036946

Bulus, M. (2005). The Investigation of the Thinking Styles Profile of Students in the Department of Elementary 
Education. Ege Education Journal, 1(6), 1-24.

Bulus, M. (2006). Assessment of Thinking Styles Inventory, Academic Achievement and Student Teacher's Characteristics. Education and Science, 31(139), 35-48.

Buyukozturk, S., Kilic Cakmak, E. K., Akgun, O. E., Karadeniz, S., \& Demirel, F. (2017). Bilimsel Arastirma Yontemleri. Pegem Publications: Ankara. https://doi.org/10.14527/9789944919289

Canbolat, N. (2011). Matematik ogretmen adaylarinin teknolojik pedagojik alan bilgileri ile dusunme stilleri arasindaki iliskinin incelenmesi. Unpublished Ms. Thesis, Selcuk University. Educational Sciences Institute, Konya.

Celik, D. (2016). 11. Sinif ogrencilerinin Dusunme stilleri, ogrenme stratejileri ve dusunme stilleri ile ogrenme stratejileri arasindaki ilişki, M.Sc Thesis, Pamukkale University Educational Science Institute, Denizli, Turkey.

Cinar, G. (2016). Ogretmen adaylarinin dusunme stilleri ile yansitici dusunme egilimleri arasindaki iliski, M.Sc Thesis, Ondokuz Mayss University Educational Science Institute, Samsun, Turkey.

Conti, G.J. (1985). The Relationship Between Teaching Style and Adult Student Learning. Adult Education Quarterly, 35(4), 220-228. https://doi.org/10.1177/0001848185035004004

Cooper, J.M. (1999). The teacher as decision-maker. In: J. Cooper (ed.), Classroom Teaching Skills (6th ed.). Houghton Miffen: Boston, pp. 1-19.

Cubukcu, Z. (2004). Determine The Thinking Styles of Teacher Candidates. Trakya University Journal of Social Sciences, 6(2), 87-106.

Cubukcu, Z. (2004a). Ogretmen adaylarının dusunme stillerinin ogrenme biçimlerini tercih etmelerindeki Etkisi. XIII.Ulusal Egitim bilimleri Kurultayi. 6-9 July 2004. Inonu University.

Dincer, B. (2009). Ogretmen adaylarının dusunme stilleri profillerinin cesitli degiskenler acisindan degerlendirilmesi, M.Sc. Thesis, Adnan Menderes University Social Science Institute, Aydin.

Dunn, R., \& Dunn, K. (1979). Learning Styles / Teaching Styles: Should They... Can They... Be Matched? Educational Leadership, 36(4), 238.

Fischer, B. B., \& Fischer, L. (1979). Styles in Teaching and Learning. Educational Leadership, 36(4), 245-254.

Grasha, A. F. (1994). A matter of style: The teacher as expert, formal authority, personel model, facilitator and delegator. College Teaching, 42(4), 12-20. https://doi.org/10.1080/87567555.1994.9926845

Grasha, A.F. (1996). Teaching with style. Pittsburgh, PA: Alliance Publishers.

Grasha, A.F. (2002). The dynamics of one-on-one teaching. College Teaching, 50(4), 139-146. https://doi.org/10.1080/87567550209595895

Heimlich, J. E., \& Norland, E. (2002). Teaching Style: Where Are We Now? New Directions for Adult ve Continuing Education, Spring (93), 17.

Ince H., Cenberci S., \& Yavuz A. (2018). The Relationship between the Attitudes of Mathematics Teacher Candidates towards Scientific Research and Their Thinking Styles. Universal Journal of Educational Studies, 6(7), 1467-1476.

Maden, S. (2012). Teaching styles of Turkish language teachers. International Journal of Turkish Literature Culture Education, 1(1), 178-200. https://doi.org/10.7884/teke.20

Nickerson, R. S. (1988). On Improving Thinking Through Instruction. Dans Review of Research in Education, 15, 3-57. https://doi.org/10.2307/1167360

Ozden, Y. (2005). Ogrenme ve Ogretme. Pegem Publications, Ankara, ss.139

Sternberg, R. J., \& Wagner, R. K. (1992). Thinking Styles Inventory. (unpublished test). Yale University.

Sternberg, R. J., \& Zhang, L. (2005). Styles of Thinking as a Basis of Differentiated Instruction. Theory into Practice, 44(3), 245-253. https://doi.org/10.1207/s15430421tip4403_9

Sternberg, R.J. (1997). Thinking styles. Cambridge: Cambridge University Press. https://doi.org/10.1017/CBO9780511584152

Tuzer, L. (2016). Sinif Ogretmenlerinin Dusunnme Stillerinin Çeşitli Değişkenler Açısından İncelenmesi, M.Sc. Thesis, Kahramanmaras, Turkey. 
Unal, M. (2017). Analysis of teaching styles of teachers and prospective teachers in terms of different variables. Abant Izzet Baysal University Journal of Faculty of Education, 17(2), 932-947.

Uredi, L. (2006). Ilkogretim 1. ve 2. Kademe ogretmenlerinin ogretme stili tercihlerine göre ogretmenlik meslegine iliskin algllarinin incelenmesi (Unpublished Ph.D. Thesis). Marmara University Social Sciences Institute, Istanbul.

Uyanik, N. (2017). Egitim fakultesi ogrencilerinin dusunme stilleri ile dusunme ihtiyaçları arasindaki iliş̧kinin incelenmesi, M.Sc. Thesis, Gaziantep University Educational Science Institute, Gaziantep, Turkey.

Yildirim, N. (2016). Ilkogretim Matematik ve Sinif ogretmenlerinin Matematik Okuryazarligi oz-yeterligi ile dusunme stilleri arasindaki ilişkinin incelenmesi, M.Sc. Thesis Thesis, Eskisehir Osmangazi University Educational Science Institute, Eskisehir, Turkey.

Zhang, L. F. (2003). Contributions of Thinking Styles to Critical Thinking Dispositions. Journal of Psychology: Interdisciplinary and Applied, 137(6), 517-544. https://doi.org/10.1080/00223980309600633

Zhang, L. F. (2005). Validating the theory of mental self-government in a non academic setting. Personality and Individual Differences, 38(8), 1915-1925. https://doi.org/10.1016/j.paid.2004.11.009

Zhang, L. F., \& Sternberg, R. J. (2002). Thinking styles and teachers' characteristics. International Journal of Psychology, 37(1), 3-12. https://doi.org/10.1080/00207590143000171 